\title{
Impact of the Morón stream on water quality of the Reconquista River (Buenos Aires, Argentina)
}

\author{
Laura de CABO', Silvana ARREGHINI',2, Alicia FABRIZIO de IORIO', Alicia RENDINA ${ }^{3}$, Marta \\ BARGIELA ${ }^{3}$, Roberto VELLA ${ }^{4}$ and Carlos BONETTO ${ }^{5}$
}

\begin{abstract}
${ }^{1}$ Museo Argentino de Ciencias. Naturales «B. Rivadavia», Av. A. Gallardo 470, C1405DJR Buenos Aires, Argentina - e-rnail: laudecab@muanbe.govar. ${ }^{2}$ Becaria Comisión de Investigaciones Científicas de la Prov. de Buenos Aires (CIC). ${ }^{3}$ Departamento de Química, Facultad de Agronomía, UBA, Av. San Martin 4453, 1417 Buenos Aires, Argentina. ${ }^{4}$ Instituto de Geocronología Isotópica, Pab. INGEIS, Cudad Universitaria, 1428 Buenos Aires, Argentina. ${ }^{5}$ CONICET. Instituto de Limnología «R. Ringuelet», Av. Calchaquí km 23.5, 1888 Florencio Varela, Prov. Buenos Aires, Argentina.
\end{abstract}

\begin{abstract}
The Reconquista River basin is located in an urban area where $2.510^{6}$ inhabitants and 4,242 industries are settled. The confluence with the Morón stream shows the largest anthropogenic impact. The effect of the Morón stream on the water quality of the Reconquista River was evaluated in relation to its organic, mineral and metal contribution. Bimonthly samplings were carried out in the Reconquista River upstream (GOR), and downstream (SMT) from the confluence with the Morón stream and in the latter (MOR). Dissolved oxygen, $\mathrm{pH}$, conductivity, temperature, transparency, nutrients, major ions, suspended solids, particulate and total organic carbon, Kjeldahl nitrogen, total phosphorus and heavy metals were determined in water samples. Discharge ratios between the Reconquista and Moxón streams were estimated based on chloride concentrations. The samplings were ordered from the Principal Component Analysis in: GOR, SMT and MOR according to a growing gradient of organic and mineral contamination. This gradient has a spatial component (related to the discharge point of the Morón stream) and one related with the flow of the Reconquista River. Mean levels of heavy metals were higher than the thresholds for aquatic life protection. The most important were: lead, zinc, copper and mainly chromium, all of them related to industrial activity. Their concentrations responded to an irregular and intermittent discharge. Sometimes, metal levels at SMT and GOR were higher than at MOR, indicating other sources of contamination besides the Morón stream.
\end{abstract}

Key words: heavy metals, Morón stream, organic contamination, Reconquista River, urban river, water quality

The Reconquista River basin has a surface of $1.6710^{5}$ hectares 72,000 are occupied by agricultural areas, mainly located in the upper basin, and 95,000 are urbanized, mostly located in the middle and lower basin. The discharge in the study. area ranges from 86,362 to $143,591 \mathrm{~m}^{3}$ day $^{-1}$ (Thames Water Consultancy Service, 1979) in agreement with the precipitation pattern. The basin comprises 14 districts with more than $2.510^{6}$ inhabitants, that represent $8 \%$ of the Argentine population (Saltiel, 1997a). Olson et al. (1998) consider that the Reconquista basin is comprised within a critical area with regard to the conservation status of freshwater ecoregions of Latin America. The main course and its tributaries receive running waters from landfills and cultivated lands as well as domestic and industrial effluents (from food, textile, rubber, chemical industries, and tanneries). Thus, there is a large contribution of organic matter and pollutants as heavy metals among others (Castañé et al., 1998; García et al., 1998), that determine a high to very high degree of contamination in the middle and low basin (Arreghini et a1., 1997).

The largest population in the basin concentrates in Tres de Febrero, San Martín, Morón and ex Gral Sarmiento districts. The mean density for the whole basin is 36.4 inhabitants hectare ${ }^{-1}$, reaching 88.5 inhabitants hectare ${ }^{-1}$ in San Martín. Only $16 \%$ of the population of the basin has sewers, and $37 \%$ has potable water (Saltiel, 1997b). The biggest spillage of industrial effluents are located in San Martín, Morón, ex Gral. Sarmiento and Tres de Febrero districts, mainly corresponding to rubber, textile, mechanics and food industries (Pescuma \& Guaresti, 1992) (Table 1). In the nine more polluted districts, the total number of industries with polluting potential is 4,242 which produce an organic load equivalent to a population of $2,467,866$ inhabitants, similar to 


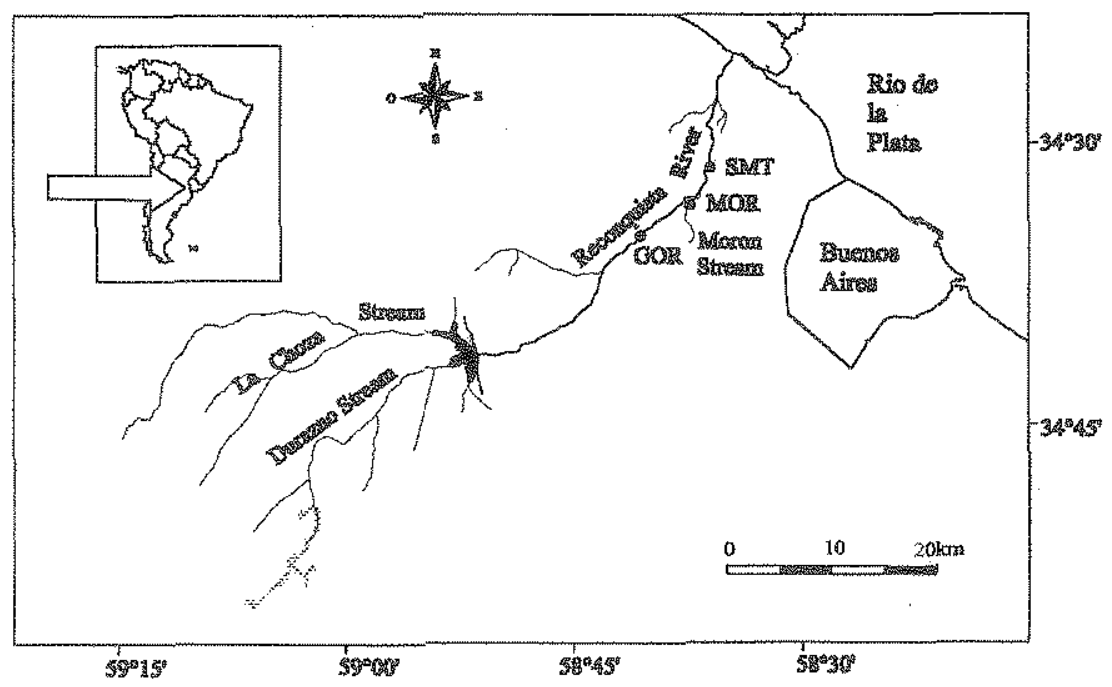

Fig. 1. Area of study (- sampling sites)

Table 1. Industrial activities of the area (Data obtained from Pescuma \& Guaresti, 1992).

\begin{tabular}{lcc}
\hline & $\begin{array}{c}\text { Volume of spilled effluents }\left(\mathrm{m}^{3} \text { day }\right. \\
\text { in } \text { Morón stream }^{\mathbf{1}}\end{array}$ \\
\hline Cattle slaughter, meats & 925 & 1.712 \\
Milk and derivatives & - & 167 \\
Cereals, flower and derivatives & 1.029 & - \\
Alcohol and alcoholic beverages & - & 71 \\
Other foods & 988 & 2.387 \\
Textile & - & 4.707 \\
Hides and skins & 3 & 1.993 \\
Cellulose, paper and graphical material & 8.472 & 1.323 \\
Rubber & 441 & 3.097 \\
Chemicals & - & 369 \\
Cement and stones & - & 38 \\
Shipyards and mechanic workshops & 95 & 3.126 \\
Steel metallurgy & 142 & 521 \\
Electrical apparatus and material & 48 & 41 \\
Metallurgy & 74 & 275 \\
lce factory & - & - \\
Photographic articles and related material & 20 & 5 \\
Various manufactures & 80 & 295 \\
Car wash (cattle trucks excluded) & 1.165 & - \\
Non industrial facilities & 36 & - \\
Laundry & 13.519 & - \\
Total & & 20.127 \\
\hline
\end{tabular}

* Considering only San Martín, Tres de Febrero, Morón and ex Gral. Sarmiento districts.

the total population of the basin (AGOSBA, 1991).

The Morón stream flows through Tres de Febrero, Morón and San Martín districts until its confluence with the Reconquista River, $17 \mathrm{~km}$ upstream from the mouth of the latter. Kuczynski (1994) analyzed some physical, chemical and microbiological variables during the decade of the $80 \mathrm{~s}$, and recorded extremely high organic and bacterial loads $\left(\mathrm{COD}=703 \mathrm{mg} 1^{-1}\right.$ and coliforms 
were occasionally higher than a million and a half ind $1-\dot{x})$. At low flow conditions, the Morón discharges are $52,000 \mathrm{~m}^{3}$ day $^{-1}$ (Thames Water Consultancy Service, 1979), depending on both precipitation and spilled effuents. Its longitude is roughly $16 \mathrm{~km}$, of which the upper $4.5 \mathrm{~km}$ are tubed.

The objective of the present study is to assess the impact of the Moron stream on the water guality of the Reconquista River in relation to organic and heavy metal contamination.

\section{MATERIALS AND METHODS}

Surface water samples were taken at three sites: Gorriti (GOR), and San Martín (SMT), on the Reconquista River located $18 \mathrm{~km}$ upstream and $1 \mathrm{~km}$ downstream respectively from the conlluence with the Morón strearn, and the Morón stream (MOR) at the bridge of Route 8 (Fig. 1). Five samplings were carried out in June, August, October and December 1996 and February 1997.

Dissolved oxygen (DO), pH, conductivity, temperature and transparency (Secchi depth) were determined in situ. Water samples were filtered through Whatman GF/C iilters, and carried in ice to the laboratory. Dissolved nutrients were determined in the filtrate. Soluble reactive phosphorus (SRP) (molybdateascorbic), nitrates $\left(\mathrm{N}-\mathrm{NO}_{3}{ }^{-}\right.$) (reduction with hydrazine sulfate), nitrites $\left(\mathrm{N}^{-} \mathrm{NO}_{2}\right)$ (diazotation) were determined after Strickland \& Parsons (1968), Ammonium $\left(\mathrm{N}-\mathrm{NH}_{4}{ }^{+}\right.$) (indophenol blue) was measured according to Mackereth et al., (1978). Calcium $\left(\mathrm{Ca}^{2+}\right)$ and magnesium $\left(\mathrm{Mg}^{2+\cdot}\right)$ (EDTA titration), sodium ( $\mathrm{Na}^{+}$) and potassium $\left(\mathrm{K}^{+}\right)$(flame photometry), bicarbonate $\left(\mathrm{HCO}_{3}{ }^{-}\right)$ (Gran titration), sulfate ( $\mathrm{SO}_{4}^{2 \cdot}$ ) (turbidimetry) and chloride $\left(\mathrm{Cl}^{-}\right)$(silver nitrate titration) were determined following APHA (1992). Dissolved inorganic nitrogen (DIN) was calculated as the sum of ammonium, nitrates and nitrites. Suspended matter (SM) was determined as the weight difference after filtration. Particulate organic matter (POC) was determined after Golterman et al. (1978) previous digestion of the filters used for SM determination. Total organic carbon (TOC) (Golterman et al, 1978), Kjeldahl nitrogen (NKj) and total phosphorus (TP) (APHA, 1992) were determined in unfiltered water samples fixed in the field with sulfuric acid.

The mean concentration of Kjeldahl nitrogen, ammonium, total phosphorus, soluble reactive phosphorus and discharge were used to estimate the daily loads at each sampling site. At low flow, discharge values estimated were 86,362 and
$143,591 \mathrm{~m}^{3}$ day $^{-1}$ in the Reconcruista River near GOR and downstream from the confluence, respectively, and $52,000 \mathrm{~m}^{3}$ day in the Morón stream (Thames Water Consultancy Service, 1979). The Morón value corresponded to a daily discharge average, and the rest was estimated from a mathematical model.

Total concentracions of metals (manganese, iron, copper, chromium, zinc, cadmium and lead) were performed according to APHA (1992) in unfiltered water samples fixed in the field with nitric acid. The determinations were carried out by inductive coupling plasm atomic emission spectrophotometer (ICPAES).

The water quality index (ICA, Berón, 1984) was calculated in each site and sampling date, considering dissolved oxygen, percentage of oxygen saturation, ammonium, chlorides and temperature. The correlations were carried out using the Spearman correlation index. The Kruskal-Wallis test was used to compare the observations between sites and sampling dates for each variable, and when significant differences were obtained, analysis of multiple comparisons was applied (Daniel, 1978). Principal Component Analysis (PCA) was carried out on the correlation matrix of the variables: dissolved oxygen, KjeldahI nitrogen, ammonium, nitrate, nitrite, total phosphorus, particulate organic carbon, total organic carbon, calcium, magnesium, sodium, potassium, bicarbonate, sulphate and chloride. Only those components leading to clear conclusions and accounting for more than $10 \%$ of total variance were considered (Pla, 1986).

\section{RESULTS}

The relative discharge at SMT with regard to MOR (Table 2), was obtained from the general dilution equation (Jolánkai, 1997):

$\left(\mathrm{Q}_{\mathrm{Gor}} * \mathrm{Cl}_{\mathrm{Gor}}\right)+\left(\mathrm{Q}_{\mathrm{Mor}}{ }^{*} \mathrm{Cl}_{\mathrm{Mor}}\right)=\left(\mathrm{Q}_{\mathrm{Gor}}+\mathrm{Q}_{\mathrm{Mor}}\right) * \mathrm{Cl}_{\mathrm{SMT}}$ considering $Q_{\text {SMT }}=Q_{\text {Gror }}+Q_{\text {Mor }}$.

Such an approach assumes steady state conditions in the water courses and instantaneous full cross-sectional mixing, and

Table 2. Relative discharge of Reconquista River at SMT.

\begin{tabular}{ll}
\hline June & $\mathrm{Q}_{\mathrm{SMT}}=2.579 \mathrm{Q}_{\mathrm{MOR}}$ \\
August & $\mathrm{Q}_{\mathrm{SMT}}=2.544 \mathrm{Q}_{\mathrm{MOR}}$ \\
October & $\mathrm{Q}_{\mathrm{SMT}}=2.935 \mathrm{Q}_{\mathrm{MOR}}$ \\
December & $\mathrm{Q}_{\mathrm{SMT}}=1.637 \mathrm{Q}_{\mathrm{MOR}}$ \\
February & $\mathrm{Q}_{\mathrm{SMT}}=5.203 \mathrm{Q}_{\mathrm{MOR}}$ \\
\hline
\end{tabular}


relies on chloride behaviour as a conservative and mobile ion.

The concentration of dissolved oxygen (Table 3 ) differed significantly among sites $(p<0.05)$ and average values at SMT were 18 times lower than at GOR, becoming occasionally anoxic at SIMT (June and December). MOR showed values of dissolved oxygen ranging from 0.1 to $0.6 \mathrm{mg} \mathrm{l}^{-1}$, the maximum being attained in coincidence with the lowest temperature (June). The temperature did not differ significantly among sites, and it followed a seasonal behavior, excluding thermal contamination. Water $\mathrm{pH}$ was alkaline.

Conductivity (Table 3) showed significant differences among sites $(p<0,001)$, the higher val ues being in MOR, (June and February). In Feb. ruary the conductivity at MOR was very high $\left(3,090 \mu \mathrm{S} \mathrm{cm}^{-1}\right)$. However, at SMT the conductivity was approximately the same as at GOR. The highest relative discharge at SMT with regard to MOR was obtained in February (Table 2).

Secchi depth (Table 3) diminished $38 \%$ and the suspended matter increased $130 \%$ at SMT with regard to GOR, presenting a significant inverse correlation $(x=-0.74 ; p<0.05 ; n=9)$.

Suspended matter was correlated directly with particulate organic carbon $(\mathrm{r}=0.73 ; \mathrm{p}<0.01$; $\mathrm{n}=13)$ and total organic carbon $(\mathrm{r}=0.59 ; \mathrm{p}<0.05$; $\mathrm{n}=13$ ).
The average of Kjeldahl nitrogen and ammonium (Table 3 ) increased $42 \%$ and $53 \%$ respectively at SMT regarding GOR. Both variables showed significant differences between sites $(\mathrm{p}<0.001)$, registering the highest values at MOR. The average of Kjeldahl nitrogen at SMT was approximately half of that at MOR. However, in December, Kjeldahl nitrogen and ammonium at SMT were similar to those at MOR related with smaller relative discharge at SMT with regard to MOR. Ammonium represented on the average from 85 to $97 \%$ of the dissolved inorganic nitrogen, the highest percentages being at SMT and MOR. Nitrates and nitrites (Table 3) showed significant differences among the sites $(p<0.001$; $p<0.01$, respectively) registering the highest values at GOR. Nitrates were correlated positively with dissolved oxygen $(r=0.82$; $p<0.001 ; n=15$ ), the highest levels of nitrates and nitrites being in coincidence with an important increment of dissolved oxygen at GOR, in December. At SMT the concentration of nitrates was six times lower than at GOR.

Soluble reactive phosphorus represents 41.5 to $67.1 \%$ of total phosphorus. The highest values in soluble reactive phosphorus and their percentages with regard to total phosphorus were registered in October and February, reaching $100 \%$ at GOR. The concentrations of soluble re-

Table 3. Physicochemical variables measured.

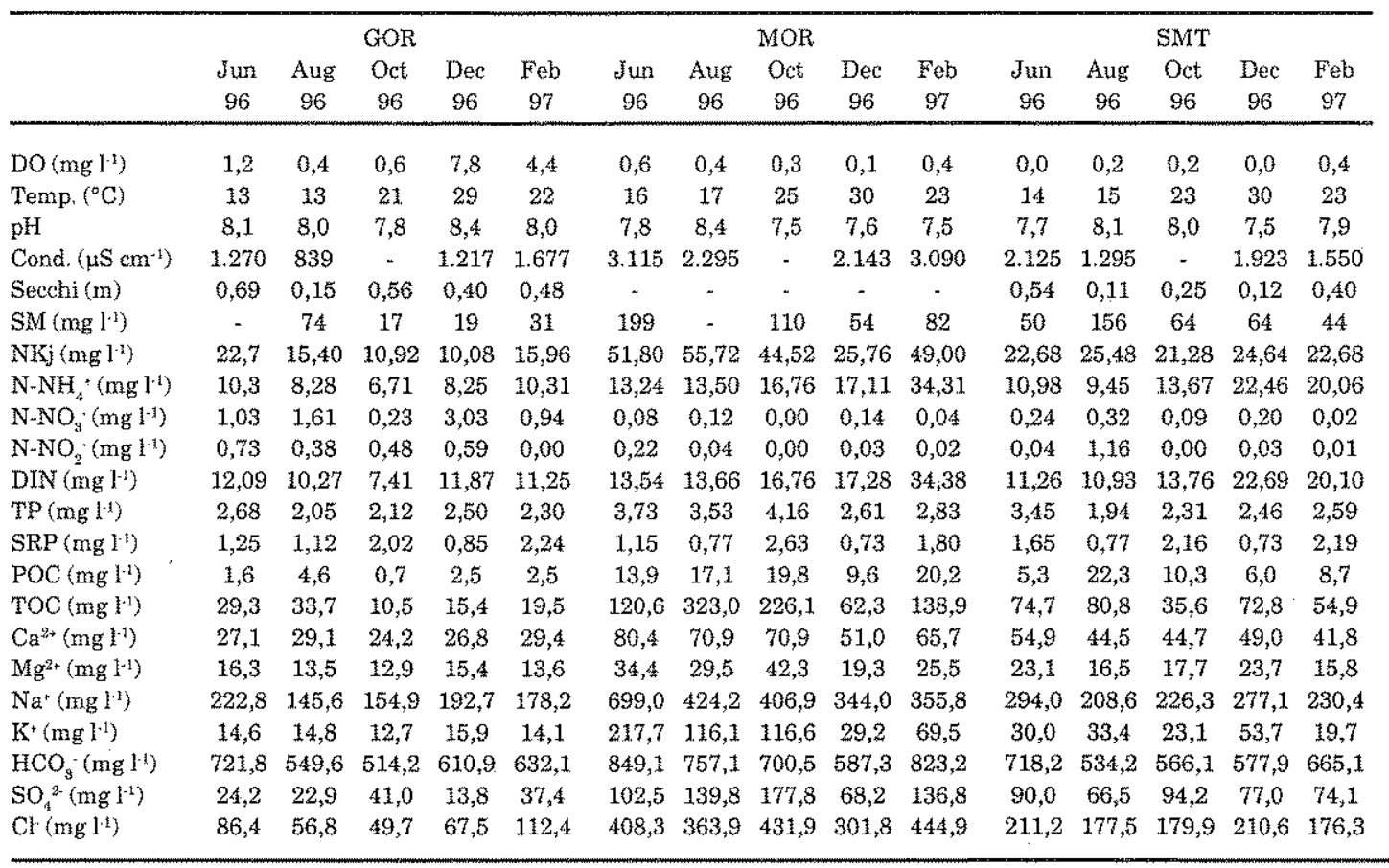


active phosphorus and total phosphorus did not register an important increase between GOR and SMT.

The levels of particulate organic carbon and total organic carbon showed significant differences among sites $(p<0.01$ and $p<0.001$ respectively), presenting the highest values in particulate organic carbon at SMT and MOR and the highest levels in total organic carbon at MOR. These variables increased 3 and 4 times at SMT with regard to GOR, indicating an important matter discharge from the Morón stream.

Bicarbonate and sodium were the principal ions in the river. The bicarbonates in the Reconquista River did not increase significantly downstream from the confluence with the Morón stream. On the other hand, calcium, magnesium, sodium, potassium, sulphate and chloride registered significant increases from $23 \%$ to $174 \%$ at SMT regarding GOR. In December, the levels of these variables at SMT were quite similar and ever higher than at MOR, in coincidence with the lower diluting effect of the Reconquista River (Table 2). In February, when the diluting effect of the Reconquista River was higher (Table 2), the levels of all variables measured at SMT were lower than at MOR.

According to ICA index, all samplings at SMT and MOR, and at GOR in October, presented sewer level contamination, and GOR in the rest of dates presented high contamination.

According to daily load balance of the main variables that reflect organic contamination (Table 4), the highest values were found at SMT, except for the total organic carbon.
In the $\mathrm{PCA}, 72.9 \%$ of the total variance was explained using two components. Component I accounted for $61.6 \%$ of the total variance and had the following variables related to its positive extreme: Kjeldahl nitrogen, total phosphorus, total organic carbon, particulate organic carbon, calcium, magnesiun, sodium, potassium, bicarbonate, sulphate, and chloride (Table 5). This component showed a spatial gradient of mineral and organic pollution along the stream. Component II accounted for $11.3 \%$ of the total variance and had dissolved oxygen related to its positive extreme. Ordination of sites in the I-II plane (Fig. 2) showed spatial location of sites along axis 1. GOR samplings were located in the left extreme. In the other extreme, the samplings of MOR were Iocated, except Decernber. In the center were located all the samplings of SMT, and December samplings of MOR. December samplings of GOR was separated by the second axis, lying within the positive region.

The metal concentrations, except cadmium, were higher on the average than thresholds proposed for aquatic life protection by Argentine Law of Dangerous Residues ( $\left.N^{\circ} 24,051\right)$ (Table 6). According to these limits, the more hazardous metals were: lead, copper, zinc and chromium. Lead, zinc and manganese levels increased to 5 times and chromium to 35 times at SMT regarding GOR. In August, the levels of heavy metals at GOR and SMT were higher than at MOR. In October, the concentration of heavy metals diminished with regard to the other samplings, the concentrations of almost all the heavy metals being lower than the levels for the protection of the aquatic life.

Table 4. Load balance of the main variables of organic contamination.

\begin{tabular}{lcccccc}
\hline & $\begin{array}{c}\mathrm{NKj} \\
\left(\mathrm{kg} \mathrm{day}^{-1}\right)\end{array}$ & $\begin{array}{c}\mathrm{N}^{\mathrm{N}} \mathrm{NH}_{4}^{+} \\
\left(\mathrm{kg} \mathrm{day}^{-1}\right)\end{array}$ & $\begin{array}{c}\mathrm{TP} \\
\left(\mathrm{kg} \mathrm{day}^{-1}\right)\end{array}$ & $\begin{array}{c}\text { SRP } \\
\left(\mathrm{kg} \mathrm{day}^{-1}\right)\end{array}$ & $\begin{array}{c}\mathrm{TOC} \\
\left(\mathrm{kg} \mathrm{day}^{-1}\right)\end{array}$ & $\begin{array}{c}\text { POC } \\
\left(\mathrm{kg} \mathrm{day}^{1}\right)\end{array}$ \\
\hline GOR & 1.318 & 791 & 211 & 139 & 1.743 & 201 \\
MOR & 2.359 & 987 & 175 & 74 & 9.057 & 838 \\
SMT & 3.116 & 2.007 & 360 & 209 & 8.211 & 1.363 \\
\hline
\end{tabular}

Table 5. Variance explained and component loadings for PCA axes III.

\begin{tabular}{ccccc}
\hline Component & Eigenvalue & $\begin{array}{c}\text { \% Total } \\
\text { Variance }\end{array}$ & $\begin{array}{c}\text { Cumulative } \\
\text { Eigenvalue }\end{array}$ & $\begin{array}{c}\text { \% Cumulative } \\
\text { Variance }\end{array}$ \\
\hline I & 9,2 & 61,6 & 9,2 & 61,6 \\
II & 1,7 & 11,3 & 10,9 & 72,9 \\
\hline
\end{tabular}




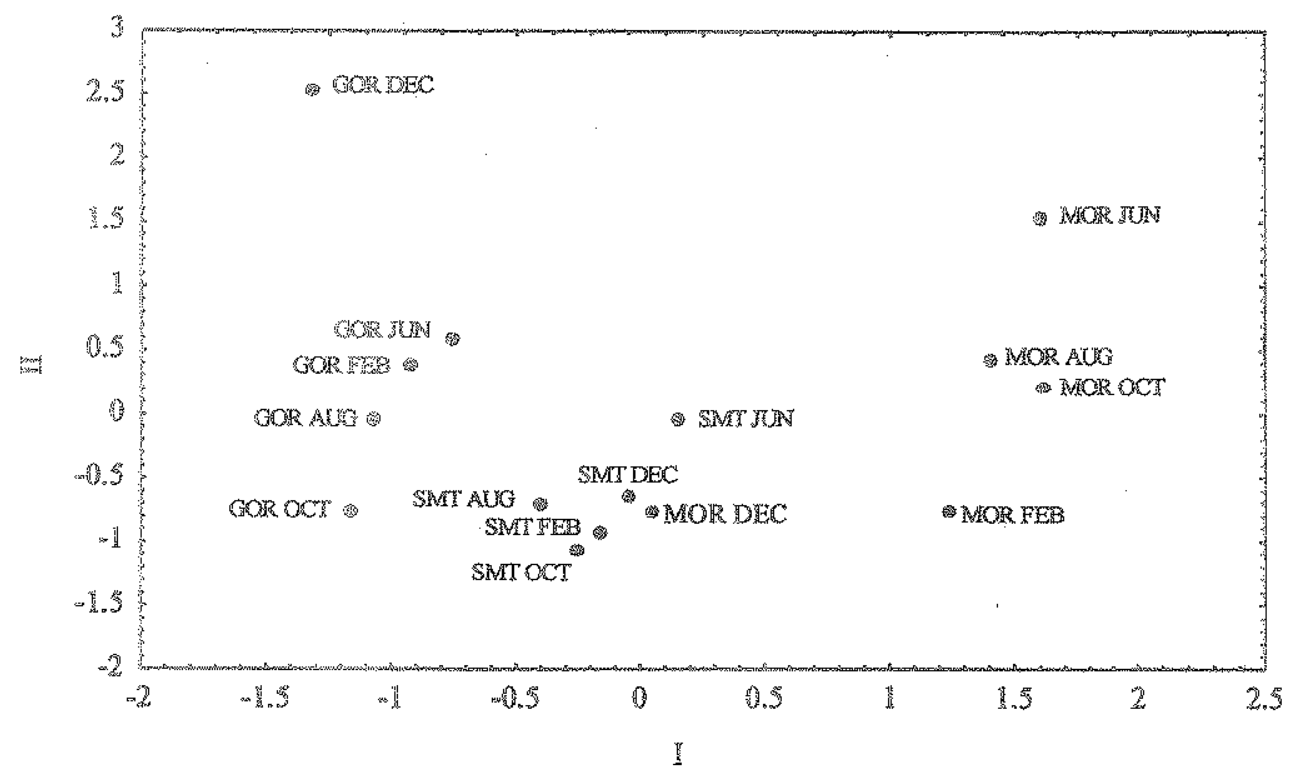

Fig. 2. Location or the samples in the plane defined by components I and II.

Table 6. Heavy metal concentrations and their respective levels proposed for protection of aquatic life by the Argentine Law of Dangerous Residues $\left(\mathrm{N}^{\circ} 24,051\right)$.

\begin{tabular}{|c|c|c|c|c|}
\hline & GOR & MOR & SMT & $\begin{array}{l}\text { Levels for protection } \\
\text { of aquatic life }\end{array}$ \\
\hline $\operatorname{Mn}\left(\mu^{2} I^{-2}\right)$ & $(64-123)$ & $(7-269)$ & $(7-299)$ & 100 \\
\hline $\mathrm{Fe}\left(\mu \mathrm{g} \mathrm{B}^{-4}\right)$ & $(362-2,570)$ & $(16-2,275)$ & $(18-3,083)$ & . \\
\hline $\left.\mathrm{Cu}(\mu \mathrm{g}]^{3}\right)$ & $(28-304)$ & $(2-142)$ & $(1-98)$ & 2 \\
\hline $\ln \left(\operatorname{mg} 1^{-1}\right)$ & $(46-147)$ & $(28-472)$ & $\left(11-\frac{1}{1} 88\right)$ & 30 \\
\hline $\mathrm{Cr}\left(\mu \mathrm{g} \mathrm{I}^{-1}\right)$ & $(2-8)$ & $(0.3-850)$ & $(0.1-561)$ & 2 \\
\hline $\mathrm{Cd}\left(\mu \mathrm{g} \mathrm{l}^{\hat{3}}\right)$ & $(0.04-1)$ & $(0.01-5)$ & $(0.004-1)$ & 0,2 \\
\hline $\mathrm{Pb}\left(\mathrm{Mg}^{3-1}\right)$ & $(13-114)$ & $(0.3-273)$ & $(0.2-130)$ & 1 \\
\hline
\end{tabular}

\section{DRCUSGRON}

Due to lack of flow data for the sampling dates in the sampling sites, the estimation of relative discharge of the Reconquista River at SMT with regard to that of the Morón stream, represented a good indicator of a relative flow variation. The average of the relative discharge estimations here reported was roughly coincident with the Reconm quista/Morón Mow ratio attained from the flow data estimated by the Thames Water Consultancy Service (1979).

The conductiwity at MOR was higher than at other sampling sites on all dates. When the relative discharge at SMT with regard to MOR was highest, the conductivity at SMT and GOR was similar. On the other hand, when the relative discharge was lowest, the conductivity at SMT was similar to that at MOR. The same effect was observed for calcium, magnesium, sodium, potassium and sulphate concentrations. The increase of river flow would contribute to attenuate the effect of the Moron stream at least regarding to these variables.

Like in other streams of Buenos Aires (López et al., 1998; Mercado, 1999), bicarbonates and sodium were the principal ions in this river.

The direct correlation between the suspended matter and particulate and total organic carbon would indicate that this matter contains 
an important organic component, contrary to the Matanza-Riachuelo River (Lopez et al., 1998) supporting similarly high pollution loads.

The level of contamination at SMT was higher than at GOR. At SMr', the high discharge of total oxganic carbon and the low levels of dissolyed oxygen, arriving at levels of almost anoxia, indicated important bacterial consumptor. Present results suggest that the high organic mabter load determines the oxygen depletion and that nitrification is limited by oxygen availability. These variables were very strongly influenced by the discharge of the Moron stream. Nevertheless, this stream did not produce an increase in the phosphorous concentrations, either soluble or total, ât SNTI.

According to the index of wate quality, $\mathrm{SM}$. and MOR always showed a contamination level similar to a sewer effuent, while at GOR the conditions were slightly better, indicating high contamination. This index confers to ammonium the highest relative weight.

The loads obtained for the different variables indicated that the important organic contamination of this river was due mainly to the Moron stream. According to load balance, we found that SMT loads corresponded approximately to the addition MOR and GOR.

According to PCA, the sites were ordered following a growing gradient of organic and mineral contamination in GOR, SMT and MOR. In December, MOR presented intermediate levels of contamination being located near the samplings of SMT. Besides, the smallest diluter effect of the Reconquista River in this month produced similar characteristics in SMT and MOR.

The levels of all metals analized were, on the average, higher than levels of protection of the aquatic life, and the most dangerous were lead, copper, zinc and chromium. The increment of lead, zinc, manganese and chromium at SMT responded to the industrial activity of the area, where the predominant are textile, chemical, tanneries and metallurgical. In August, the levels of heavy metals at GOR and SMT were higher than at MOR, indicating important contributions of toxic pollutants to the river besides the Moron stream. The heavy metal concentration was not related to the relative discharge at SMT and could be attributed to an irregular and intermittent spillage of toxic effluents.

\section{CONCLUSIONS}

According to the variables involved in the organic contamination, MOR was the site with the most human impact, followed by SWIT and GOR.

The gradient of organic and mineral contamination of the Reconquista River had a spatial component and another one related to the flow. "The first component was given wainly by the discharge of the Morón stream. "The second component was related to the dilution level of ito wasters.

Considering the levels of heavy metal in water, the tendencies were quite irregular havimg on occasions a higher toxic load at SNIT and GOR than at MOR. The toxic contamination by heavy metals depended mainly on the interwithent and irregular discharge of the affuents. Ix this river. the level of this kind of contamination wonid not depend on the llow.

In order to perform river restoration plans and to evaluate water quality it is indispensable to keep in mind the value discharge and the precipitation régime. Also, although the Moron stream is the main responsibie for the deterioration of the Reconquista River, other pollutant discharges exist in punctual and diffuse form that worsen this situation.

\section{ACKNOWLEDGEMENTS}

We acknowledge Prefectura Naval Argening for supporting the field trips during samplings and Lic. Roberto Serafin for collaboration in data statistical analysis.

\section{BIBLIOGRAPHY}

AGOSBA. 1991. Plan de Control de la Contaminación Industrial en la Cuenca del Rio Reconquista. Ministerio de Obras y Servicios Públicos, La Plata, Provincia de Buenos Aires, Argentina.

APHA - AWWA - WPCE. 1992. Métodos normalizados para el análisis de aguas potables y residuales. Ed. Díaz de Santos. S.A, Madrid.

Arreghini, S., L. de Cabo, A.F, de Iorio, A. Rendina, M. Bargiela, G. Godoy di Pace, A. Corujeira, R. Vella, y C. Bonetto. 1997. Evaluación de la calidad de aguas del Río Reconquista a través de índices. Congreso Internacional sobre Aguas, Facultad de Derecho, UBA.

Berón, L. 1984. Evaluación de la Calidad de las Aguas de los rios de La Plata y Matanza-Riachuelo, mediante la utilización de indices de calidad de agua. Secretaría de Vivienda y Ordenamiento Ambiental, Minis terio de Salud y Acción Social, Buenos Aires, Argentina.

Castañé, PM., M.L. Topalián, M.G. Rovedatti \& A. Salibian. 1998. Impact of human activities on the water quality of the Reconquista River (Buenos Aires, Argentina). Verh. Internat. Verein. Limnol, 26: 1206-1208. 
Daniel, WW 1978. Applied Nonparametric Statistics. Houghton Mifflin Company, Boston, $513 \mathrm{pp}$.

Gaxcía, M.E.; S.O. Demichelis, F.R. de la Torre, \& L. Ferrari. 1998. Freshwater toxicity to Cnesterodon $s p .:$ bioassays with water from the Reconquista River. Verh. Internat. Verein. Limnol. 26: 1216-1218.

Golterman, H., R. Clymo, \& M. Ohndtad. 1978. Methods for the physical and chemical examination of freshwaters. Blackwell Sci. Publ., Oxford, $166 \mathrm{pp}$.

Jolánkai, G. 1997. Basic niver water quality models. Computer aided learning (CAL) programme on water quality modelling. IHPV, Technical Documents in Hydrology $\mathrm{N}^{\circ} 13$, UNESCO, Paris, $50 \mathrm{pp.}$

Kuczyngki, D. 1994. Estudio Ambiental de un curso de agua urbano altamente deteriorado por acción antropógena (arroyo Morón, provincia de Buenos Aires, Argentina). Revista de Ecología Médica y Salud Ambiental. 1(4): 1+14.

López, L.C., A. Magdaleno, L. de Cabo, M.F. Noriega, M. Bassi, S. Arreghini, G. Bassols, M. Wagner y J. Moretion. 1998. Estudios de mutagenicidad, inhibición del crecimiento algal y contaminación química en aguas superficiales de un rio urbano de Buenos Aires, Argentina. Rev. Int. Contam. Ambient. 14 (1): 27.37.

Mackereth, F., J. Meron \& J. Talling. 1978. Water Analysis: some revised methods for limnologists. Freshwater Biological Assoc. Scientific Public. N 36 , $120 \mathrm{pp}$.

Mercado, L.M. 1999. Consideraciones acerca de la calidad de las aguas de seis sistemas lóticos de la Pro- vincia de Buenos Aires (Argentina). APRONA, Año XII, N'38: 10-16.

Olson, D., E. Dinerstein, P. Canevari, I. Davidson, G. Castro, V. Morisset, R. Abell \& E. Toledo. 1998. Freshwater biodiversity of Latin America and the Caribbean: A conservation assessment. Biodiversity Support Program, Washington D.C, 70 pp.

Pescuma, A. \& M.E. Guaresti. 1992. Proyecto de Sanewmiento Ambiental y Conirol de Inundaciones de la Cuenca del Rio Reconquista. Informe final. Buenos Aires, Argentina.

Pla, L.E. 1986. Multivariate Analysis: Principal Components Methods. Organization of American States, Washington D.C, 94 pp. (in Spanish).

Saltiel, G. 1997a. Situación zambiental en la cuenca hídrica del Río Reconquista. Problemas y soluciones. Prin mera parte. Ingeniería Sanitaria y Ambiental 31: 4555 .

1997b. Situación ambiental en la cuenca hídrica del Río Reconquista. Tercera parte: el proyecto de saneamiento. Ingeniería Sanitaria y Ambiental 34: 4654.

Strickland, J. \& T. Parsons. 1968. A practical Handbook for seawater analysis. Bulletin 167.J. Fish. Res. Bd. Can., Ottawa, Canadá.

Thames Water Consultancy Service. 1979. Investigación sobre la contaminación del Rio Reconquista. Informe. Buenos Aires, Argentina.

Recibido: 28-IV-2000 Aceptado: $15-\operatorname{IX}-2000$ 